大量下血をきたし緊急手術となった虚血性直腸炎の 1 例

国立栃木病院外科，同病理*

片井均 丸谷巌 丸上善久 高野 真澄

中村 修三 富田 濤児西田一已*

\title{
A CASE OF ISCHEMIC PROCTITIS REQUIRING EMERGENCY OPERATION FOR THE MASSIVE BLEEDING
}

\section{Hitoshi KATAI, Iwao MARUYA, Yoshihisa MARUGAMI, Masumi TAKANo, Syuzou NAKAMURA, Touji TOMITA and Kazumi NISHIDA* \\ Department of Surgery, *Department of Pathology, National Tochigi Hospital}

棎引用語：虚血性直腸炎

\section{はじめに}

虚血性大腸炎は直腸には起こり難いといわれてい る、今回，われわれは，広範な直腸粘膜の壊死を起こ し大量下血のため，緊急手術となった 1 例を経験した ので報告する，さらに文献的に集計しえた本邦直腸発 生例23例について若干の検討を加充た。

$$
\text { 症例 }
$$

患者：57歳，女性

主訴：突然の下血

既往歴：昭和 42 年子宮筋腫で手術，昭和 54 年クモ膜 下出血, 高血圧

家族歴：特記すべきことなし

現病歴および経過：1984年 9 月26日，左被殸出血を 起こし，当院脳外科にて 9 月28日に血腫腔ドレナージ 術を施行し，順調に経過していた．10月22日（発症第 1 日目）夕方，突然，多量の新鮮血を下血した。血圧 の低下をきたしたため，輸血を開始し，止血剤を投与 しながら経過をみていたが，出血が持続したため10月 24日（第 3 日目）消化器外科へ依頼となった。同日， 大腸内視鏡を施行した。まず直腸鏡にて多量の凝血塊 を十分に吸引した後，大腸ファイバースコープを择入 した，直腸粘膜の広範な壊死と出血を認め，保存的療 法では止血は不可能と判断して手術に踏及切った。 術後は，残存大腸の出血なく経過良好であったが， 12月18日脳幹梗塞にて死亡した。

大腸内視鏡所見：下部直腸上り $\mathrm{S}$ 状結腸に地図上

$<1985$ 年 9 月11日受理>別刷請求先：片井均

干320 宇都宮市中戸祭 1-10-35 国立杤木病院外 科
に著明な粘膜の壊死を認め, 壊死の間に健常粘膜を認 める肚門縁より $50 \mathrm{~cm}$ まで插入したが $15 \mathrm{~cm}$ より口側 は粘膜の発赤を認めるが，壊死は認められず，出血部 位は直腸であると診断した。

手術所見：下腹部正中切開にて開腹, 大腸全体に血 液を透見する。漿膜面は汪とんど異常なく，わずかに， 直腸膨大部に出血斑を認める。術式は Hartmann 手術 を施行した。下部直腸を十分に剥離し健常部で切断, 肛門側断端は閉鎖した。側結腸は病変部位より十分 に距離をとり切離し, 直腸および $\mathrm{S}$ 上結腸を $32 \mathrm{~cm}$ 切 除，口側断端を人工肛門とした。

図 1 大晹内視鏡像・下部直腸に全周性の謴場を認め る.

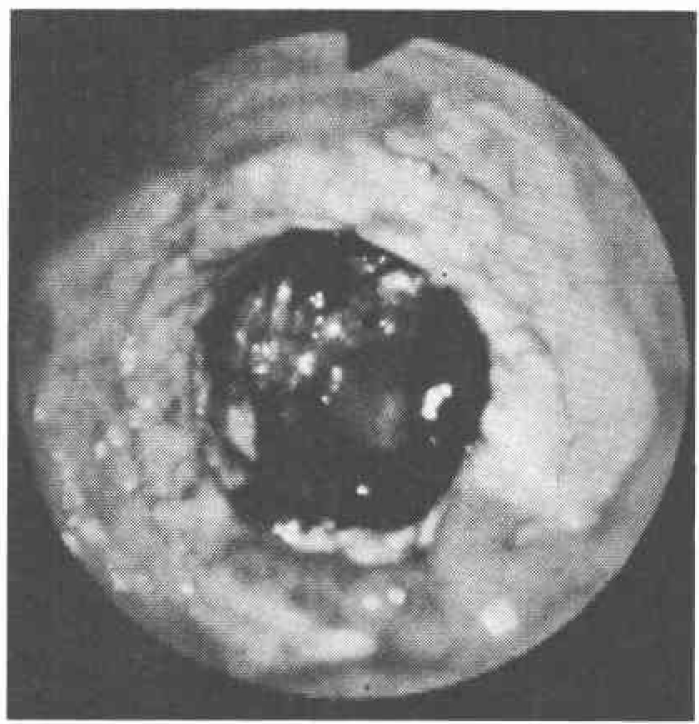


切除標本所見：下部直腸に全周性の境界明瞭な潰煌 を認め，一部に暗茶黑色の壊死物と白いフィブリンが 混じった污い苔が付着している，さらに，その口側に 同様な3/4周の潰瘍を認める。潰瘍の間に島状の健常部 を残寸 (図 2 ).

病理組織学的所見：肉眼的に大きな潰瘍形成部には 線維素, 炎症細胞, 壊死物質, 出血からなる偽膜がみ

図 2 切除標本. 広範な潰瘍を認めその間に島状の健 常を見る.

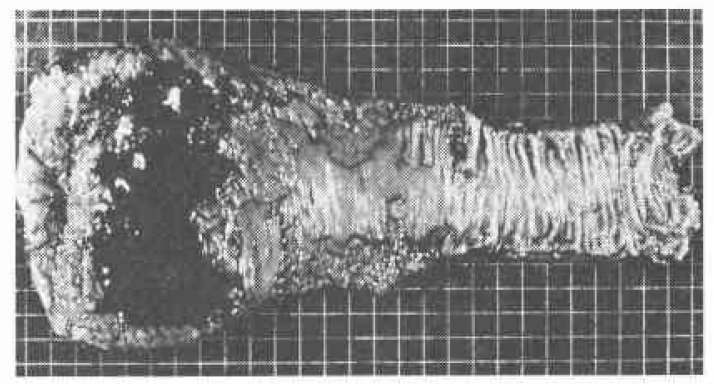

因 3 病理組織像. 偽膜形成を伴う U1 IV の潰瘍

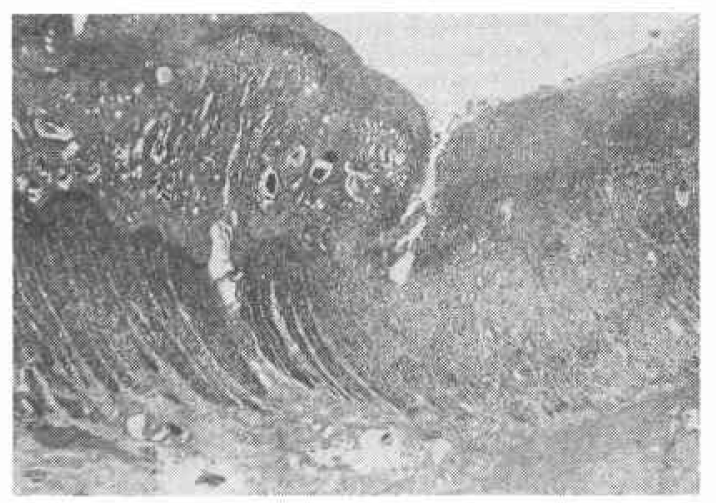

図 4 病理組織像. 粘膜下層に小血管の増生と充血を 認め, 同時に動脈の狭窄も認める.

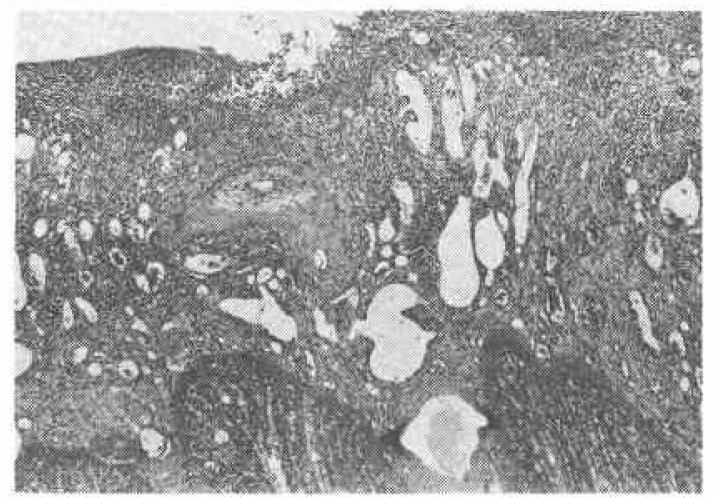

られ，強い粘膜下層の浮腫とともに筋層にも強い炎症 の波及をみる。潰瘍中心部では筋層は完全に破壊され， U1 IV の肉芽組織と化し, 墏膜層にも線維性の肥厚を みる(図 3)，粘膜下層では小血管が強く増生し，充血 をきたし，ところどころで囊胞状に拡大している。 そ の中に出血血管としての動脈があり，その内膜，中膜 の肥厚による狭窄像が散見される（図4）。

以上の所見から急性期の虚血性大腸炎と診断した。

\section{考 察}

虚血性大腸炎は1963年のBoley ${ }^{11} ら ， 1966$ 年の Marston') らの発表以来, 広く認識され, 近年その報告 例は急速に増加している。

\section{1. 分類}

Marston $^{2}$ らは本症を1. gangrenous form, 2. stricturing form, 3. transient form の 3 つに分類し

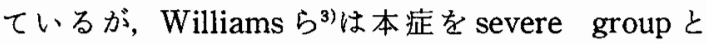
mild group に分類すればよいとしている。また，手術 時の動脈切断などの原因の明らかな二次的なるのと自 然発生的なものに分類し，自然発生的なものを spontaneous ischemic colitis と呼んでいる.

\section{2. 年齢，基礎疾患}

高齢者に多く, 50 70歳台に多い. 竹本 ${ }^{4)} ら は$ 平均年 齢58.0歳, 三島5)らは62歳と. 報告している。循環器系の 基礎疾患を有していることが多く, 本症例のように高 血厈を有するものは三島5)らによると，34\%と最も多 い.

\section{3. 発生部位}

発生部位は左側結腸に圧倒的に多く，従来は Giffith' s point ${ }^{6)}$ である脾曲部が好発であるとされていたが， 脾曲部はむしろ少なく結腸左半遠位側が多いとされて いる.一般に，直腸では，下腸間膜動脈系の血流とと もに内腸骨動脈系の血流があるために発生はまれであ るとされている，直腸発生例は川崎》らの $15.2 \%$ と比 較的多い報告もあるが，三島5らによると5.1\%（7/ 130), 竹本 ${ }^{4}$ らによると $2.2 \%$ (1/45) であり, さらに 高橋8)らは本邦例，外国例を集計し，それぞれ4.5\%(9/ 132），5.6\%（23/238）と報告しており，少ない。

\section{4. 病因}

血流豊かな直腸に虚血性大腸炎が生じる要因とし $て$, Nelson ${ }^{9}$ らは直腸は血流豊富だが, 側副血行路の発 達が遅いことを挙げている。従って腹部大動脈瘤の手 術など広籁な腹部血管手術後で突然, 下腸間膜動脈な どの主幹動脈が閉塞された場合などには起こりらると

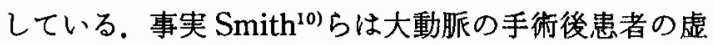


表 1 本邦直腸発生例

\begin{tabular}{|c|c|c|c|c|c|c|c|}
\hline No & 報告者 & 年龄性 & 基礎疾患 & 症状 & 部位 & 病型 & 治 療 \\
\hline 01 & 廣田 ${ }^{14)}$ & $25 \sigma^{7}$ & & 腹満 & $\mathbf{R}$ & mild & 值腸切除 \\
\hline 02 & 武藤 15 ) & $800^{x}$ & $\mathrm{~S}$ 状結腸癌術後 & 腹痛 & $\mathrm{D} \sim \mathrm{R}$ & mild & 保存的 \\
\hline 03 & 堀江 ${ }^{16)}$ & $540^{7}$ & 左下肢切断後 (ASO) & 下血 & $\mathrm{T} \sim \mathrm{Rs}$ & mild & 保存的 \\
\hline 04 & 堀江 & $800^{7}$ & 直腸癌術後 & 下血 & $T \sim R$ & mild & 保存的 \\
\hline 05 & 堀江 & $660^{7}$ & 脳卒中発作直後 & 下血 & $S \sim R$ & mild & 直腸切除 \\
\hline 06 & 堀江 & $650^{7}$ & 脳卒中発作 2 週間後 & 下血 & $S \sim R$ & mild & 保存的 \\
\hline 07 & 堀江 & $83 \sigma^{7}$ & TIAの翌日 & 下血 & $\mathrm{D} \sim \mathrm{Rs}$ & mild & 保存的 \\
\hline 08 & 煀江 & $65 \sigma^{7}$ & & 下血 & $S \sim R s$ & mild & 保存的 \\
\hline 09 & 堀江 & 75우 & & 下自 & $\mathrm{D} \sim \mathrm{R}$ & mild & 下行結腸部分切除 \\
\hline 10 & 堀江 & $77 \sigma^{7}$ & & 下血 & $S \sim R s$ & mild & 保存的 \\
\hline 11 & 堀江 & $67 \sigma^{7}$ & 腹部大動脈瘤術後 & 腹膜炎 & 回 $\sim \mathrm{R}$ & severe & 小腸, 全結晹切除 \\
\hline 12 & 柴田 ${ }^{17)}$ & 70 우 & & 下血 & 全大腸 & severe & 全結腸切除 \\
\hline 13 & 勝又 ${ }^{18)}$ & $70 \sigma^{7}$ & 脳血管障害 & 下血 & $\mathrm{Ra}$ & mild & 保存的 \\
\hline 14 & 高橋19) & $63 \sigma^{7}$ & フレルギー性血管炎 & 下血 & $\mathrm{R}$ & mild & 保存的 \\
\hline 15 & 高橋 & 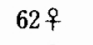 & 高血王 & 下血 & $\mathrm{R}$ & mild & 保存的 \\
\hline 16 & 武藤20) & 65 우 & 腹部大動脈瘤 & 下血 & Rs & mild & 保存的 \\
\hline 17 & 武藤 & $54 \Im^{7}$ & ASO 術後 & 下血 & $S \sim R$ & mild & 保存的 \\
\hline 18 & 武藤 & $650^{x}$ & 糖尿病, 脳血栓 & 下血 & $S \sim R$ & mild & 保存的 \\
\hline 19 & 武藤 & $80 \overbrace{}^{7}$ & 直腸癌術後 & 下血I & $\mathrm{T} \sim \mathrm{R}$ & mild & 開腹 \\
\hline 20 & 武藤 & $74 \sigma^{7}$ & & 下血 & $S \sim R$ & mild & 保存的 \\
\hline 21 & 山城 ${ }^{211}$ & 76 ㅇ & 脸卒中発作後 & 下组 & $S \sim R$ & mild & 保存的 \\
\hline 22 & 山城 & $710^{7}$ & 腎不全 & 下痢 & $S \sim R$ & mild & 保存的 \\
\hline 23 & 自験例 & 57 우 & 脳出血 & 下血 & $S \sim R$ & severe & 直腸切除 \\
\hline
\end{tabular}

血性大腸炎 12 例を報告しているが，そのうち 8 例が直 腸に発生している。表 1 は文献的に集計しえた本邦直 腸発生例23例の概要であるが，そのうち6 例は腹部大 動脈の手術をうけたり直腸癌の手術をうけ下腸間膜動 脈の処理をされたりしている。しかし，本症例のよう に特にそのような既往のないものも多い。

5. 病理

病理組織学的には, 病変は U1 I, U1 II の浅いものが 多く"1)，本症例のようにUI IV にまで達するものは少 ない.また, 特徴的とされているへモジデリン沈着や, 壁内微小血管閉塞像, フィブリン血栓などが認められ る例は少ない5).

\section{6. 診断}

虚血性大腸炎の診断には，内視鏡，注腸，血管造影 などがそれぞれ有用であるが, 本症例のような激症例， 特に直腸に病変がある場合は内視鏡が最も有用である と思われる。やっかいな前処置なしで施行でき，直腸 鏡で凝血塊を十分に排除した後, 病变部の観察が可能 である。ささら手術時の切除線決定の際，重要な情報 を提供してくれるからである。

7. 治療

保存的療法で治瘦する症例が多く，手術例は川崎》
らによると25\% (31/125)，三島5)らによると33\%(44/ 133）と少ない。本邦直腸発生例では $30 \%(7 / 23)$ であ る.三島5らによると施行術式は好発部位より，S 状結 腸切除, 結腸左半切除が多く, 直腸切断例は 2 例と非 常に少ない，われわれの直腸発生例の集計でも直腸切 除をうけたるのはわずか 3 例である。本症例に対して われわれは Hartmann 手術を施行したが，このよらな severe type の症例には出血のコントロール.穿孔の可 能性から積極的に手術を施行すべきであると考える。 Marston ${ }^{12)}$ らは手術適応を次のよらに考古ている，1） 腸管壊死，2）持続性の出血，3）腸閉塞症状，4）悪性 の可能性である. 本邦直腸発生例では腸管壊死のため 手術となったのは全大腸型の 2 例で, 出血のため手術 となったのは本症例だけである。実際, 川崎》らは本例 のように出血性ショックになる症例は少ないと報告し ている.さらに症例 1 が狭窄症状のため, 症例 5,6 が悪性の可能性のため手術を受けている。ささて, 手術 に際しては腸切除の範囲が問題となるが, 漿膜病変よ りも粘膜病変の方がはるかに広範であるため壊死腸管 を完全に切除するための切除線の決定が重要である. そのためにも，先に述べたように内視鏡で十分に粘膜 面を観察することが重要である，特に值腸に病変があ 
る場合は下部直腸を十分に剥離し肛門側を内視鏡で確 認した健常部で切離することが望ましい. Hunt ${ }^{13)}$ は穿 孔前に病変腸管を完全に切除できれば一期的に吻合可 能であると述べているが, 病変が下部大腸にあり, 本 例のように severe typeの場合は患者の全身状態が悪 く, 緊急で十分に bowel preparation がなされていず, しかも患者に老人が多く高血圧, 糖尿病などの合併症 を有していることが多いことなどからす，縫合不全の 可能性が高いので,一期的吻合は避けるべきであろう. 両端を腸㾇とするかあるいは Hartmann 手術が適当 であると思われる。

\section{結語}

大量下血により緊急手術となった虚血性直腸炎症例 を報告した。

\section{文献}

1) Boley SJ, Schwartz S, lash J et al: Reversible vascular occlusion of the colon. Surg Gyencol obstet $116: 53-60,1963$

2) Marston A, Phrils M, Thomas ML et al: Ischaemic colitis. Gut $7: 1-15,1966$

3) Williams LF, Wittenberg J : Ischemic colitis : An useful clinical diagnosis. but isit ischemic ? Ann Surg 182 : 439-448, 1975

4）竹本忠良, 川井啓市, 渡辺正俊沵か：虚血性大腸炎 の臨床. 胃々腸 $16: 259-265,1981$

5）三島好雄, 重松 宏, 堀汇良秋：虚血性大腸炎の臨 床病態一アンィートを中心に一. 厚生省特定疾患, 炎症性腸管障害に関する調査研究班, 昭和56年度 業績集, 東京, 厚生省, 1982, p338-342

6) Meyers MA : Griffith' point: Critical anastomosis at the splenic fluxure: Significance in ischemia of the colon AJR $126: 77-94,1976$

7）川崎浩史, 多淵芳樹, 大山 正ほか：虚血性大腸炎 の自験例並びに本邦集計例の検討. 外科治療
$52: 12-18, \quad 1985$

8）高橋忠雄, 日野恭徳, 山城守也：虚血性大腸炎. 臨 成人病 $13: 1741-1746,1983$

9) Nelson RL, Schuler JJ: Ischemic proctitis. Surg Gyencol Obstet $154: 27-33,1982$

10) Smith RF, Szilagi DE : Ischenmia of the colon as a complication in the surgery of the abdominal aorta. Arch Surg 80:806-821, 1960

11）岩下明徳, 飯田三雄：虚血性大腸炎の病理. 胃と腸 $16: 245-257,1981$

12) Marston A: Intestinal Ischemia. London, Edward Arnold, 1977, p156-171

13) Hunt DR: Surgical management of ganerenous ischemic colitis: Report of five cases. Dis Colon Rectum $20: 36-39,1977$

14）廣田耕二, 松本孝一, 浦 伸三ほか：若年者阻血性 腸炎かと思われる 1 症例。外科 $39: 833-836$, 1977

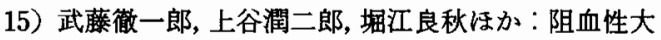
腸炎. 臨外 $33: 310-311,1978$

16）堀江良秋, 三島好雄, 武藤徹一郎注か：阻血性腸疾 患见関する臨床的研究. 日消病会誌 76 ： 1768-1781, 1979

17）柴田晃毅，山下三千年：虚血性大腸焱の一剖検例。 日赤医 $32: 88,1980$

18）勝又伴栄, 真玉寿美生, 岡部治弥汪か：早期静脈相 の出現を認めた一過性虚血性大腸炎の 1 例. 胃と 腸 $16: 287-290,1981$

19）高橋日出雄, 東郷実元，穴沢占夫ほか：虚血性大腸 炎 3 例の臨床像之病理組織所見. 日本大腸肛門病 会誌 $33: 368,1980$

20）武藤徹一郎, 上谷潤二郎, 沢田俊夫浶か：虚血性大 腸炎。内科鏡と生検を中心飞。胃と腸 16 ： $267-274,1981$

21）山城守也：虚血性大腸炎の臨床的特徵。日本大腸 肛.門病会誌，34：593-598，1981 